\title{
IRON AND STEEL SLAG: AN ALTERNATIVE SOURCE OF RAW MATERIALS FOR PORCELAIN CERAMICS
}

\author{
SIDDIQUI A. R. ${ }^{1}$ \\ PAL M. ${ }^{2}$ \\ BHATTACHARYA D. ${ }^{1}$ \\ DAS S.K. ${ }^{2, *}$
}

Received: $17 / 09 / 2013$

Accepted: 04/06/2014

Available online: 11/06/2014

\author{
${ }^{1}$ Materials Science Centre \\ Indian Institute of Technology \\ Kharagpur 721302, India \\ ${ }^{2}$ CSIR-Central Glass and Ceramic Research Institute \\ 196, Raja S. C. Mullick Road, Kolkata 700032, India
}

*to whom all correspondence should be addressed: e-mail: swapan@cgcri.res.in

\begin{abstract}
Iron and steel industry generates substantial amount of inorganic solid wastes namely blast furnace (BF), Linz-Donawitz (LD) slag from the metallurgical process and fly ash from thermal power plant which creates environmental pollution when dumped in open land. In this investigation, BF and LD slag are incorporated in quartz free fly ash based porcelain system and changes in their properties, phase and microstructural evolution were studied. The samples shown very high flexural strength (>50 MPa) in the temperature range of $1200-1300{ }^{\circ} \mathrm{C}$. Appearance of anorthite crystals were observed when feldspar is gradually replaced by $\mathrm{BF}$ and LD slag. The body with a combination of BF slag and feldspar possesses the highest strength $(90 \mathrm{MPa})$ due to the presence of mullite grains and fewer fracture origins caused by large difference in the thermal expansion coefficient between the glassy matrix, quartz and anorthite grains during cooling process. Total replacement of feldspar by equal percentage of BF and LD slag resulted formation of almost $100 \%$ anorthite grains with distinct change in crystal morphology. A strong pre-stress is produced on the glassy phase that surrounds the anorthite grains by the large difference in thermal expansion coefficient between the glassy phase and anorthite grain.
\end{abstract}

Keywords: BF slag, LD Slag; Fly Ash; Anorthite; Strength; Porcelain.

\section{Introduction}

Environmental legislation and regulations, and economics of disposal are directing the iron and steel industry to look for ways and means of minimizing the waste generation and maximizing the recycling of collected waste including addition of values to it so as to make them into economical and useful products. The steel industry worldwide paid a great deal of attention and significant progress has been made in this direction. It is reported (Mukherjee and Chakraborty, 1999) that solid wastes generation has been brought down to well below $200 \mathrm{~kg}$ per tonne of crude steel in some countries compared to around 600-1000 kg per tonne of crude steel in India. BF (Blast Furnace) slag forms the greatest portion of steel works and its principle constituents are $\mathrm{SiO}_{2}, \mathrm{Al}_{2} \mathrm{O}_{3}, \mathrm{CaO}$ and $\mathrm{MgO}$. Without recognizing its inherent scientific value, this slag was initially used as a substitute for existing load construction materials, but with rapid progress of $R \& D$, this slag in granulated form is now considered for application in cement industries. Steel making slag from basic oxygen furnace (BOF/LD slag) is one of the ferruginous wastes which have high fluxing due to presence of $\mathrm{CaO}$ and $\mathrm{MgO}$. Free lime content of this 
slag is a major environmental concern due to its swelling characteristics under wet conditions and cannot be used without weathering for several months. Fly ash is one of the most prominent and detrimental solid waste generated by iron and steel industries which draws its power requirements through captive thermal power plant. It is one of the most abundant residues of coal combustion which is composed of very fine crystalline/aluminas dust. It is known that crystalline siliceous dust causes chronic lung disease and increase risk of tuberculoses (Cowie, 1994). Moreover, exposure to crystalline silica causes silicosis, which ultimately leads to lung cancer and other chronic renal disease including rheumatoid arthritis (Gottesfeld et al., 2008). Hence, this deadly waste has been the subject of great concern to the public. An attempt has been made in this study to utilize the above hazardous solid wastes of iron and steel industries as an inexpensive source of raw materials for tri-axial porcelain bodies.

Normal tri-axial porcelain body consisting of kaolin, quartz and feldspar has been long established. Several authors studied the phase and microstructure evolution in normal porcelain body and established its relationship with mechanical properties (Barbieri et al., 1994; Sugiyama et al., 1996; Carty and Senapati, 1998; Dondi et al., 1999; Leonelh et al., 2001). Quartz and mullite are found as major crystalline phases and glass as amorphous phase. Based on the quantitative estimation of these crystalline phases the body usually designated as quartz or mullite porcelain. Studies are also carried out for the improvement of the mechanical strength of tri-axial porcelain bodies by controlling the size of quartz grain and incorporation of calcined alumina (Khandelwal and Cook, 1970; Haman et al., 1991, 1992; Harada et al., 1996). Carty and Senapati, (1998) reported the beneficial effect of cristoballite formation in porcelain for its increased strength and lower strain development during cooling process. Smaller sized grain of cristoballite and lower inversion temperature than quartz is responsible for this benefit. Due to gradual depletion of natural minerals, there is a strong need to evolve alternative sources of raw materials for manufacturing porcelain body for various classes of household and technical applications. Dana et al., (2004) reported the enhancement of strength in normal porcelain body by increasing the mullite content through partial substitution of quartz by fly ash. Kumar et al., (2001) produced high strength porcelainized stoneware body by replacing a part of clay with fly ash. Dana and Das, (2004) studied the effect of blast furnace slag, a by-product of Indian Iron and Steel plant in normal porcelain body by replacing a part of feldspar. They found that gradual replacement of feldspar by blast furnace slag resulted evolution of anorthite phase with disappearance of mullite and quartz phases. The same authors (Dana and Das, 2003) developed highest strength ceramic floor tiles utilizing blast furnace slag collected from Indian Iron and Steel plant. Marghursian and Yekta, (1994) developed single first fired ceramic wall tiles from Iranian iron slags. Sarkar et al., (2010) studied the effect of electric arc-furnace slag in ceramic tile composition replacing feldspar. The recent study of Das et al., (2013) confirm the formation of anorthite, mullite, fayalite, quartz, enstatite when LD slag (which is also called as Basic oxygen furnace slag) used in tri-axial porcelain composition.

In the present study, the effect of substitution of feldspar in partial or full by metallurgical slags (LD \& $\mathrm{BF}$ ) in quartz free tri-axial porcelain system has been investigated. The phase-microstructure-property correlationship has been established from the data of vitrification study, flexural strength, X-Ray Diffraction (XRD) pattern, Scanning Electron Microscopy (SEM) with EDAX analysis.

\section{Experimental Procedure}

The raw materials used in the present study were collected from various places of India such as Kaolin (Rajmahal, Bihar), feldspar (Hyderabad, Andhra Pradesh), LD \& BF slag, fly ash (Iron \& Steel plant, thermal power plant). A quantitative chemical analysis was carried out on all the raw materials. Gravimetric method (Hillebrand and Lundell, 1953) was utilized to determine $\mathrm{SiO}_{2}$ and $\mathrm{Al}_{2} \mathrm{O}_{3}$, whereas $\mathrm{Fe}_{2} \mathrm{O}_{3}, \mathrm{CaO}$ and $\mathrm{MgO}$ were estimated volumetrically. Alkalies were determined by flame photometry. One kilogram of each batch (AP-1, AP-2, AP-3 and AP-4) was prepared according to batch composition presented in Table 1. In the present study, quartz is fully substituted by fly ash in a clay-quartz-feldspar based tri-axial porcelain system. Feldspar is gradually replaced by BF and LD slag. 
Table 1. Batch compositions (wt \%)

\begin{tabular}{cccccc}
\hline CODE & Kaolin & Fly ash & Feldspar & BF slag & LD slag \\
\hline AP-1 & 45 & 25 & 30 & NIL & NIL \\
\hline AP-2 & 45 & 25 & 10 & 20 & NIL \\
\hline AP-3 & 50 & 30 & NIL & NIL & 20 \\
\hline AP-4 & 50 & 20 & NIL & 15 & 15 \\
\hline
\end{tabular}

All the batches were wet ground separately in a pot mill for a duration of $10.0 \mathrm{~h}$ to obtain the desired particle size. The slurry obtained was screened through 150 mesh BS sieve and dried at $110{ }^{\circ} \mathrm{C}$ for $24 \mathrm{~h}$ till the moisture content reduce to less than $0.5 \%$. The cake thus obtained was powdered to break the agglomerate and granulated for better compaction using 6-7\% moisture. The powders were compacted in the form of cubes of size $(60 \times 60 \times 60) \mathrm{mm}$ by hydraulic press (uniaxial mode) at $400 \mathrm{Kg} \mathrm{cm}^{-2}$. The dried samples were fired at four different temperatures in the range of $\left(1150-1300{ }^{\circ} \mathrm{C}\right)$ for a soaking period of 30 minutes in an electrically operated laboratory furnace using on/off control system.

Finally, the heated samples were subjected to physical tests such as linear shrinkage (LS), bulk density (BD) and apparent porosity (AP). Bulk density and \% apparent porosity of the heated samples were measured using the conventional liquid displacement method according to Archimedes principle. Flexural strength (three point bending) of the heated samples was determined by universal testing machine (INSTRON 5500R). The results reported here are the averages of six samples.

$X$-ray diffraction studies of the selected heated samples were carried out to study the phase evolution during heating. Philips ' $X$-Pert Pro diffraction unit, attached with secondary monochromator, automatic divergence slit and nickel filter, was used to get monochromatic $\mathrm{Cu}-\mathrm{K} \alpha$ radiation. The instrument was run at step scan mode with step size (0.01) and 20 is the time per step, within $2 \theta$ angle $20^{\circ}$ to $80^{\circ}$. The collected data was refined using Mode software. X-pert plus based on Rietveld were used to calculate the percentage of mullite quartz and anorthite phases. For reliability of data, each sample was scanned several times. The fitted curve matched well with the raw data and "goodness of fit" varied from 2.5 to 4 among different samples.

For scanning electron microscopic (SEM) study, samples were polished to $1 \mu \mathrm{m}$ finish with diamond paste after initial grinding with $\mathrm{SiC}$ powder and water. The polished surfaces of such samples were washed with alcohol solution at room temperature $\left(35^{\circ} \mathrm{C}\right)$. Then the samples were thermally etched at $470{ }^{\circ} \mathrm{C}$ for $20 \mathrm{~min}+$ chemical etching with $5 \% \mathrm{HF}$ solution followed by gold sputter coating. SEM was used for obtaining secondary electron images (SEI) of polished and etched surfaces and EDAX analysis was done as per normal procedure on selected position.

\section{Results and discussion}

Chemical analysis of the raw materials as oxide content is provided in Table 2. Kaolin and feldspar is of normal type commonly used in porcelain body. Fly ash contains some unburnt carbon which resulted around 4.58 wt\% loss on ignition along with $\mathrm{Fe}_{2} \mathrm{O}_{3}$ and $\mathrm{TiO}_{2}$ in higher side. Both $\mathrm{BF}$ and $\mathrm{LD}$ slag contains higher percentage of alkaline earth oxides ( $\mathrm{CaO}$ in the range of $39-44 \%$ and $\mathrm{MgO}$ in the range of $8-10 \%$, respectively). It may be further noted that $\mathrm{LD}$ slag contain considerable amount of $\mathrm{Fe}_{2} \mathrm{O}_{3}$ (around $30 \%$ ) which may be due to conversion of metal iron to $\mathrm{Fe}_{2} \mathrm{O}_{3}$ during oxygen lancing process in LD converter. The oxide compositions of each batch are also provided in Table 3. It may be observed that AP1 without LD and BF slag contain highest amount of silica, alumina and alkaline minerals than others and it belongs to normal porcelain family although quartz is fully substituted by fly ash. The compositions AP2, AP3 and AP4 contain BF and LD slag in single or in combination. Accordingly the alkaline earth oxide content of these compositions is higher than AP1. AP4 is rich in $\mathrm{CaO}$ (12.57wt \%) and $\mathrm{MgO}$ (2.75wt \%). 
Table 2. Chemical analysis of the raw materials (wt \%)

\begin{tabular}{cccccc}
\hline Major chemical constituents & Kaolin & Fly ash & Feldspar & BF Slag & LD Slag \\
\hline $\mathrm{SiO}_{2}$ & 60.25 & 63.39 & 66.81 & 35.74 & 8.34 \\
\hline $\mathrm{Al}_{2} \mathrm{O}_{3}$ & 26.32 & 25.89 & 18.08 & 14.76 & 1.13 \\
\hline $\mathrm{Fe}_{2} \mathrm{O}_{3}$ & 0.59 & 1.50 & 0.24 & 0.53 & 29.82 \\
\hline $\mathrm{TiO}_{2}$ & 1.12 & 1.56 & Traces & 0.58 & 0.77 \\
\hline $\mathrm{CaO}$ & 0.14 & 0.67 & 1.03 & 38.99 & 43.67 \\
\hline $\mathrm{MgO}$ & 0.09 & 0.58 & 0.23 & 7.80 & 9.70 \\
\hline $\mathrm{K}_{2} \mathrm{O}$ & 0.40 & 0.91 & 10.94 & 0.59 & 0.04 \\
\hline $\mathrm{Na}_{2} \mathrm{O}$ & 0.38 & 0.39 & 1.69 & 0.25 & 0.21 \\
\hline $\mathrm{LO}$ & 10.50 & 4.58 & 0.54 & 0.54 & 6.14 \\
\hline
\end{tabular}

Table 3. Oxide composition of different batches (wt \%)

\begin{tabular}{ccccc}
\hline Oxide & AP-1 & AP-2 & AP-3 & AP-4 \\
\hline $\mathrm{SiO}_{2}$ & 62.99 & 56.77 & 50.79 & 49.40 \\
\hline $\mathrm{Al}_{2} \mathrm{O}_{3}$ & 23.73 & 23.66 & 21.14 & 20.71 \\
\hline $\mathrm{Fe}_{2} \mathrm{O}_{3}$ & 0.60 & 0.68 & 6.71 & 5.15 \\
\hline $\mathrm{TiO}_{2}$ & 0.89 & 0.95 & 1.80 & 2.10 \\
\hline $\mathrm{CaO}$ & 0.51 & 8.10 & 8.95 & 12.57 \\
\hline $\mathrm{MgO}$ & 0.23 & 1.75 & 2.21 & 2.75 \\
\hline $\mathrm{K}_{2} \mathrm{O}$ & 3.86 & 0.45 & 0.77 & 0.49 \\
\hline $\mathrm{Na}_{2} \mathrm{O}$ & 0.75 & 0.12 & 0.70 & 0.41 \\
\hline $\mathrm{LOI}$ & 5.70 & 5.60 & 6.80 & 5.57 \\
\hline
\end{tabular}

To understand the densification behaviour, the samples heated at different temperatures were subjected to various physico-mechanical tests. The variation in $\mathrm{LS}, \mathrm{BD}, \mathrm{AP}$ and flexural strength are graphically represented in Figures 1-4, respectively.

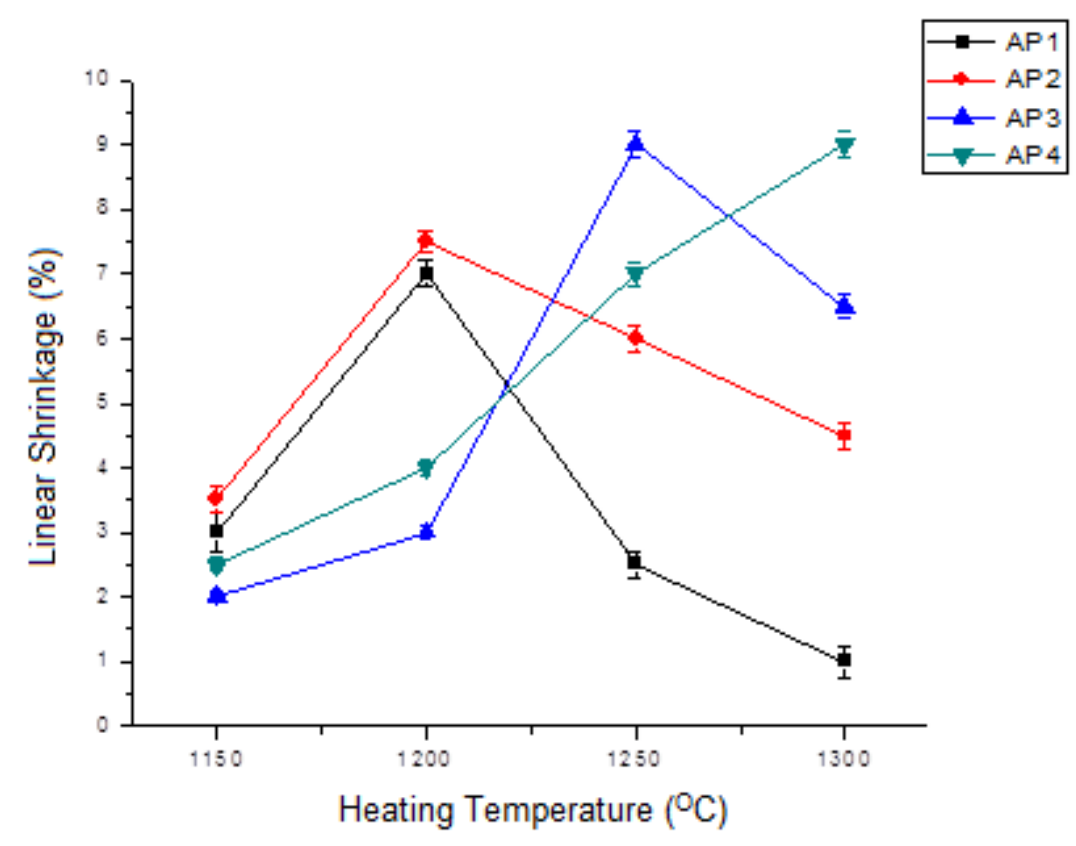

Figure. 1. Variation in linear shrinkage with heating temperature 


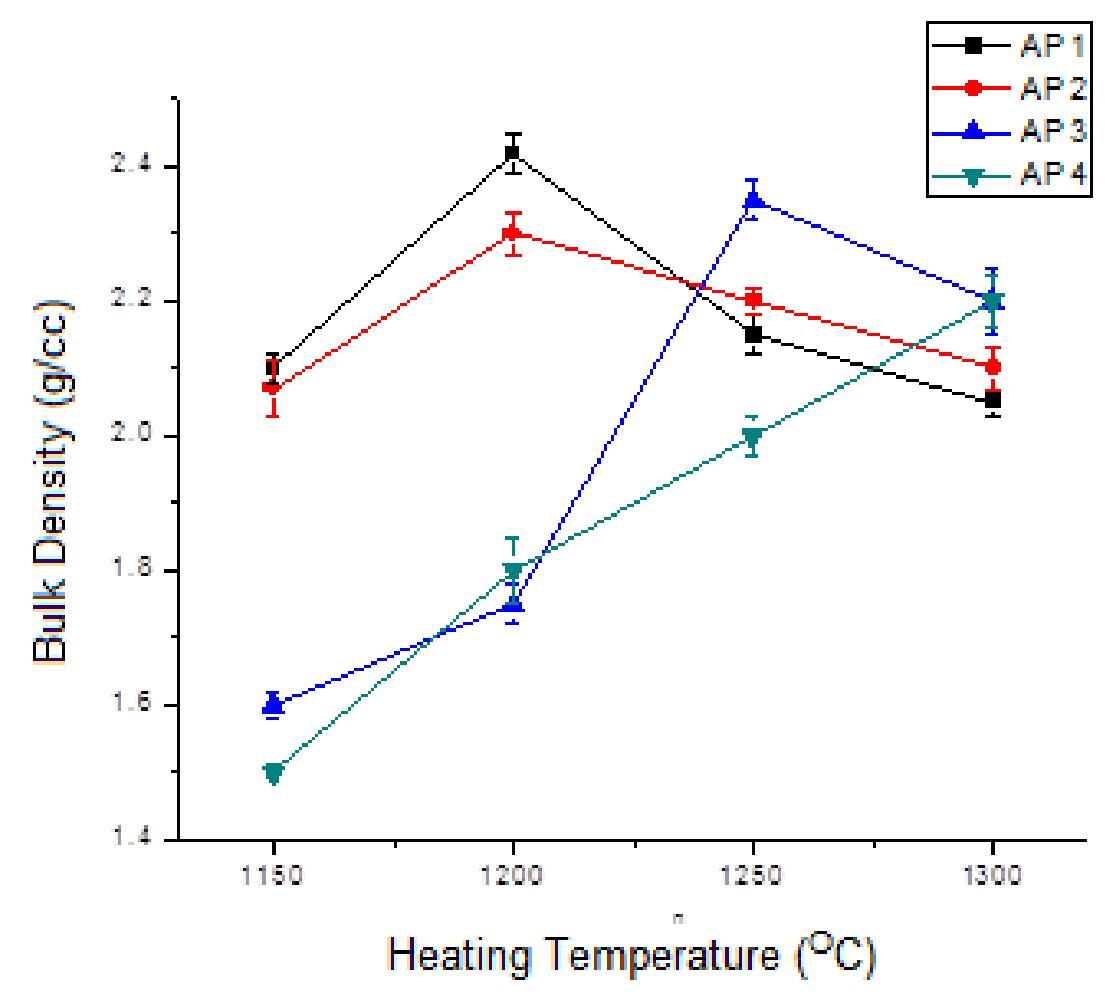

Figure 2. Variation in bulk density with heating temperature

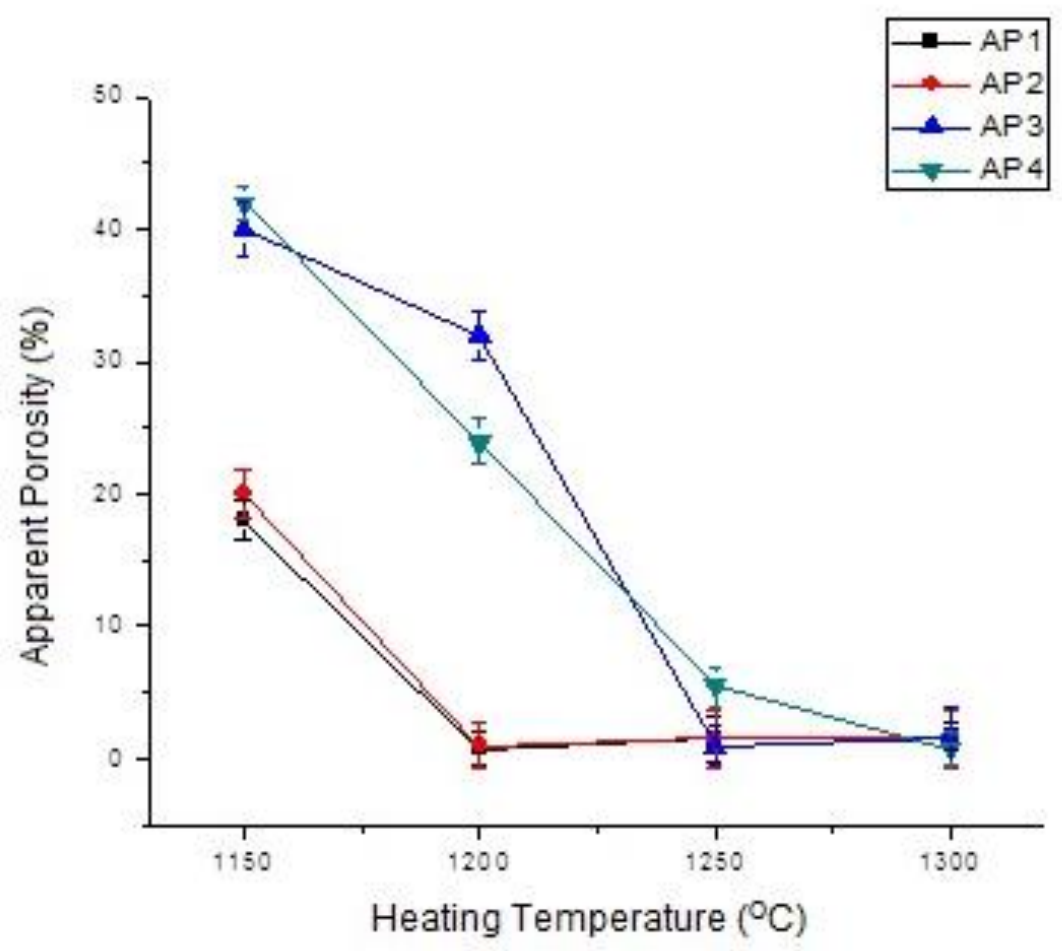

Figure 3. Variation in apparent porosity with heating temperature 


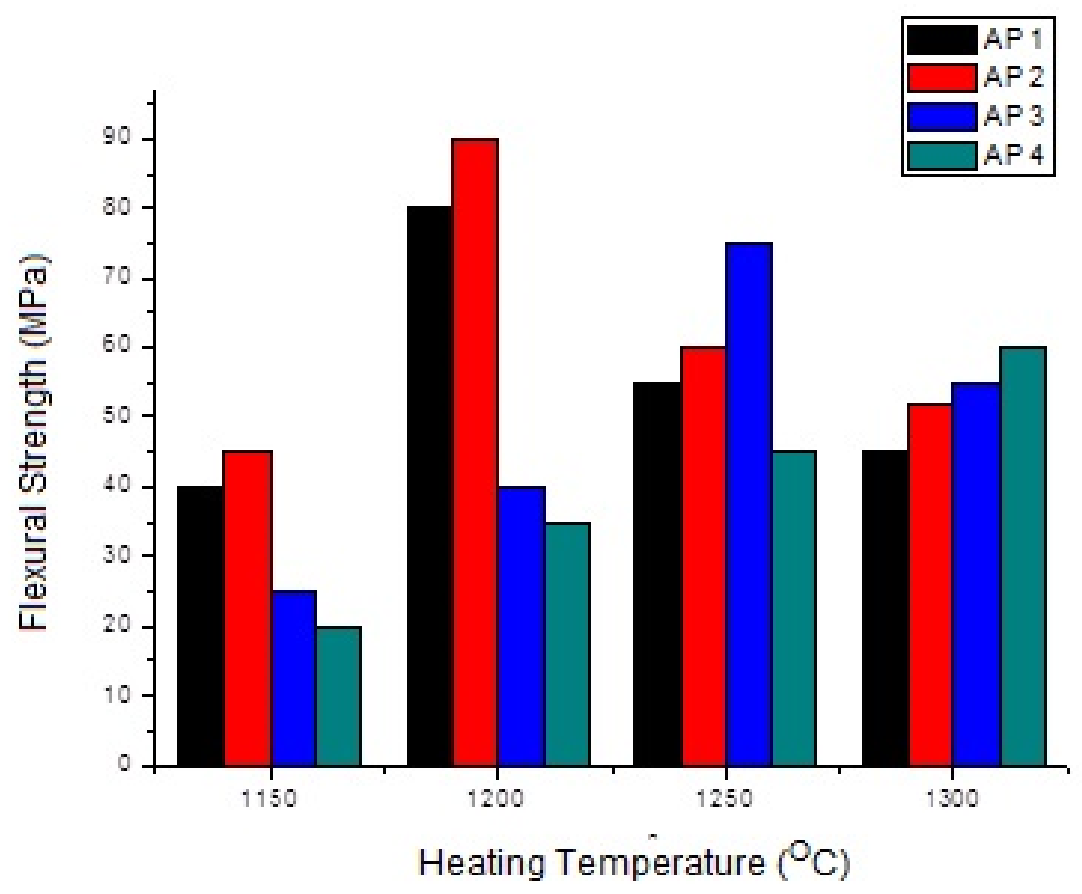

Figure 4. Variation in flexural strength with heating temperature

It may be observed that as the heating temperature increases, the LS and BD continue to increase, reached a maximum at $1200{ }^{\circ} \mathrm{C}$ for AP1 and AP2 \& at $1250{ }^{\circ} \mathrm{C}$ for AP3 and then decreased. The decreasing density after reaching maximum is attributed to pore volume expansion arises from higher pressure of gases entrapped within the closed pores at higher temperature. Similar effect was observed by Taskiran et al., (2005) in their study on the development of anorthite porcelain from natural minerals. The density is maximum in case of AP1 as it contains more mullite and it is relatively lower in case of AP2, AP3 and AP4 due to gradual formation of anorthite crystals. It is known that density of anorthite is low compared with that of mullite (Tai et al., 2002). It may also be seen from Figures 1 and 2 that in case of AP4, the LS and BD continue to increase with increase in heating temperature till the vitrification is achieved at $1300{ }^{\circ} \mathrm{C}$. Figure 3 shows variation in apparent porosity with heating temperature. As observed, AP1 and AP2 achieved less than $1.0 \%$ porosity at $1200{ }^{\circ} \mathrm{C}$, whereas AP3 and AP4 required higher temperature to achieve the same porosity level $\left(1250^{\circ} \mathrm{C}\right.$ for AP3 and $1300^{\circ} \mathrm{C}$ for AP4). Synergistic effect of alkali minerals and alkaline earth oxide to bring early vitrification is missing in case of AP3 and AP4 body, which do not contain feldspar. Figure 4 shows the flexural strength behaviour of the samples heated in the temperature range of $1150-1300^{\circ} \mathrm{C}$. Following the trend in variation of bulk density with temperature of heating, the flexural strength of AP1, AP2 and AP3 also continue to increase with increase in heating temperature, reached maximum and then decreased. In case of AP4, the strength value continues to increase till the vitrification temperature is achieved. As high as $90 \mathrm{MPa}$ flexural strength is obtained in AP2 sample at vitrified temperature of $1200{ }^{\circ} \mathrm{C}$ due to its phase assemblage and advantageous microstructural features.

The phases evolved in vitrified samples were investigated by X-ray diffraction analysis and the patterns are exhibited in Figure 5. The major crystalline phases identified are quartz and mullite in AP1; anorthite, quartz and mullite in AP2; anorthite and quartz in AP3; and mainly anorthite in AP4. Gradual appearance of anorthite phase and its increase in intensity may be observed when BF and LD slag are incorporated in the composition. As the heating progress, the melted glassy phase crystallizes and becomes anorthite. Replacement of feldspar by slag resulted disappearance of quartz and mullite, which was also observed by Dana and Das, (2004) and the quantity of anorthite phase increased with increase in slag content. The presence of higher amount of $\mathrm{CaO}$ in AP4 results only anorthite as major phase. 
The quantitative X-Ray analysis was carried out on the vitrified specimens. It was found that the composition without slag (AP1) contains $~ 60 \mathrm{wt} \%$ glassy phase and $\sim 40 \mathrm{wt} \%$ crystalline phase (Rahim, 2012), which is almost similar to conventional porcelain (Taskiran et al., 2005). On the contrary, anorthite based porcelain developed in the study (AP2, AP3 and AP4) contains 70wt\% crystalline phase with only $\sim 30$ wt\% glassy phase (Rahim 2012). Taskiran et al., (2005) also found almost similar percentage of crystalline and glassy phases in anorthite based porcelainized stoneware body. The percent of different crystalline phases present in the samples are summarized in Table 4. It was found that quartz and mullite content is gradually replaced by anorthite when slag is added in AP1. Comparing the stoichiometric composition of anorthite $\mathrm{CaO} . \mathrm{Al}_{2} \mathrm{O}_{3} .2 \mathrm{SiO}_{2}\left(43.10 \mathrm{wt} \% \mathrm{SiO}_{2}, 36.76 \mathrm{wt} \% \mathrm{Al}_{2} \mathrm{O}_{3}\right.$ and $20.14 \mathrm{wt} \% \mathrm{CaO})$, AP4 batch is expected to give more amount of anorthite.

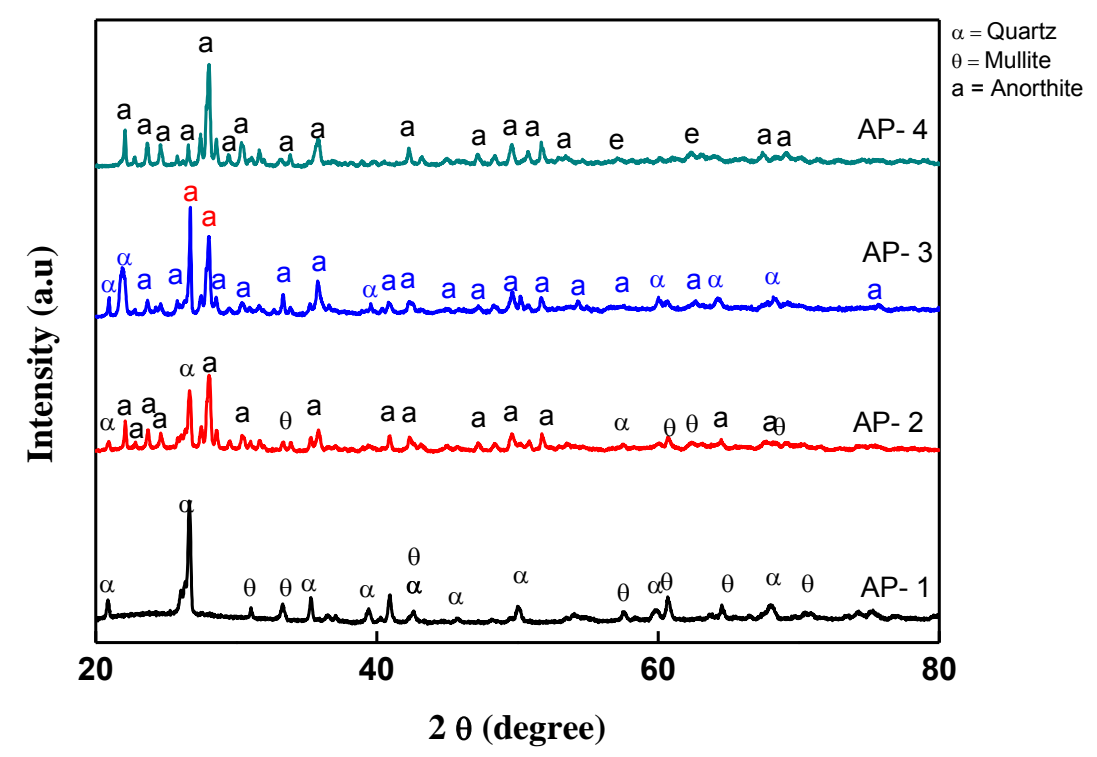

Figure 5. XRD pattern of vitrified samples

Table 4. Quantitative X-Ray analysis of crystalline phases

\begin{tabular}{cc}
\hline Sample Code & Weight $\%$ \\
\hline AP1 & Quartz $=33.38$, Mullite $=66.61$ \\
\hline AP2 & Quartz $=10.55$, Mullite $=20.15$, Anorthite $=69.28$ \\
\hline AP3 & Quartz $=10.53$, Anorthite $=89.46$ \\
\hline AP4 & Anorthite $=\sim 100$ \\
\hline
\end{tabular}

Figures 6 and 7 show the highly crystalline microstructure of mullite based (AP1) and anorthite based (AP2, AP3 and AP4) vitrified porcelain body developed in the present study. AP1 shows the presence of quartz and cluster of mullite grains distributed in the matrix. EDAX analysis supports the presence of corresponding elements towards formation of quartz and mullite crystals. There is distinct change in morphology between AP1 (without anorthite grain) and AP2, AP3 and AP4 (with anorthite grain). Relatively smaller size quartz and mullite grains in AP2 and quartz grain in AP3 are distributed between the anorthite grains. The EDAX analysis supports the presence of calcium element towards formation of anorthite phase in AP1, AP2 and AP3. Higher flexural strength (90 MPa) in AP2 body is attributed to the presence of mullite grains and fewer fracture origins and stronger pre-stress caused by large difference 
in the thermal expansion coefficient between the glassy matrix and the quartz, and anorthite grains during the cooling process. Similar observations made by Tai et al., (2002) in their study on formation of anorthite porcelain using non-plastic materials.

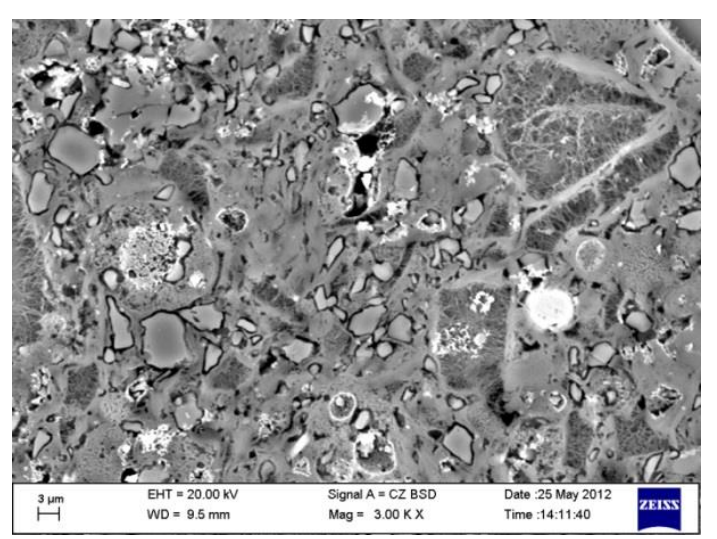

(a)

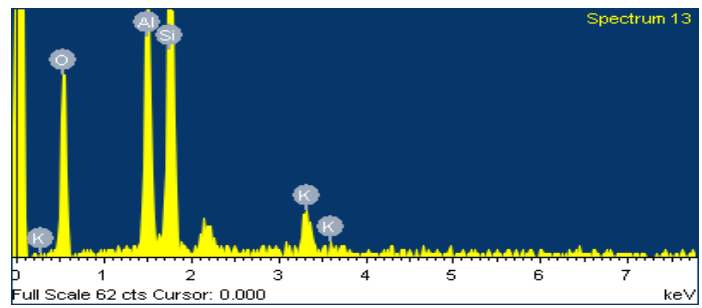

(b)

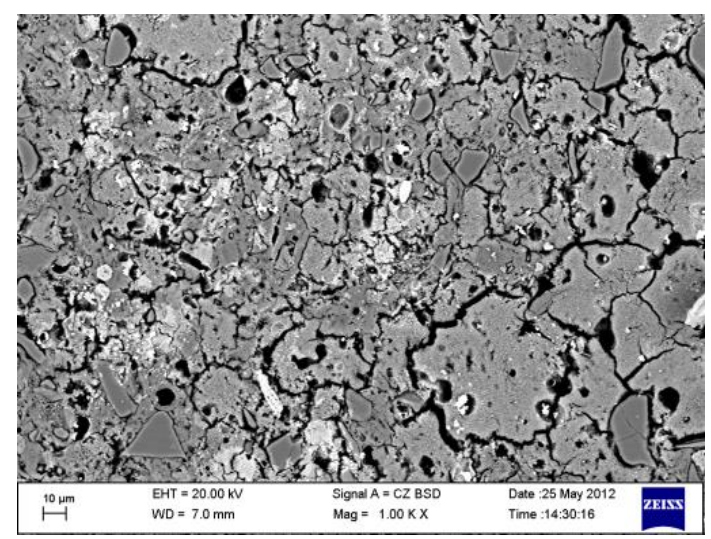

(c)

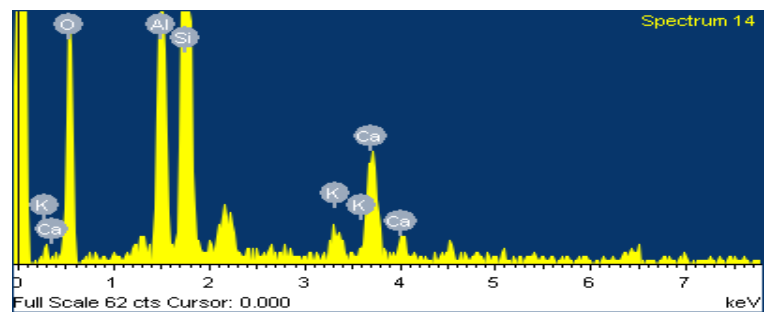

(d)

Figure 6. The microstructure and EDAX analysis of polished and etched specimens vitrified at $1200{ }^{\circ} \mathrm{C}$ (a \& b )-AP1, (c \& d)-AP2.

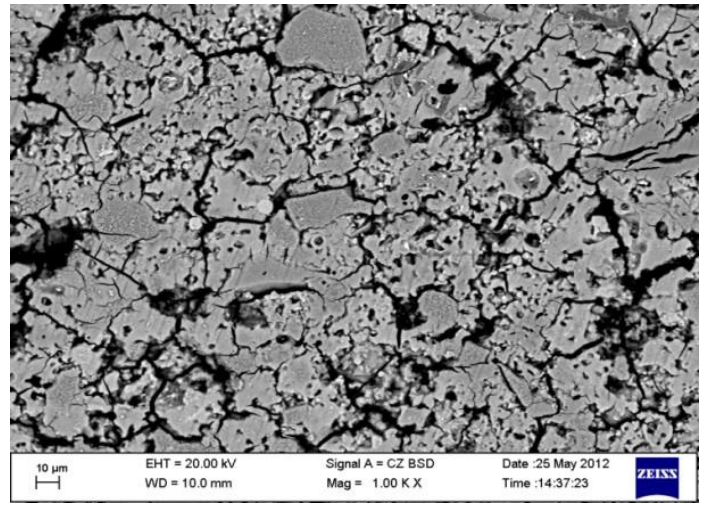

(e)

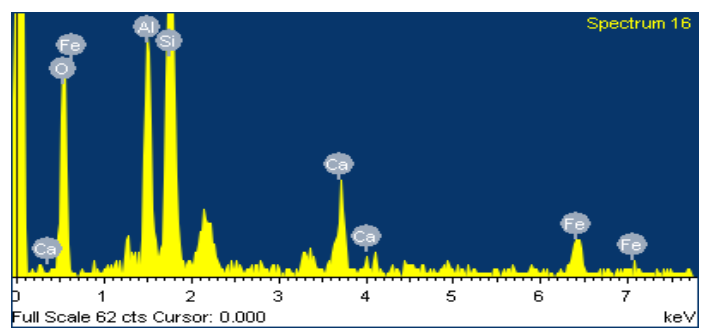

(f)

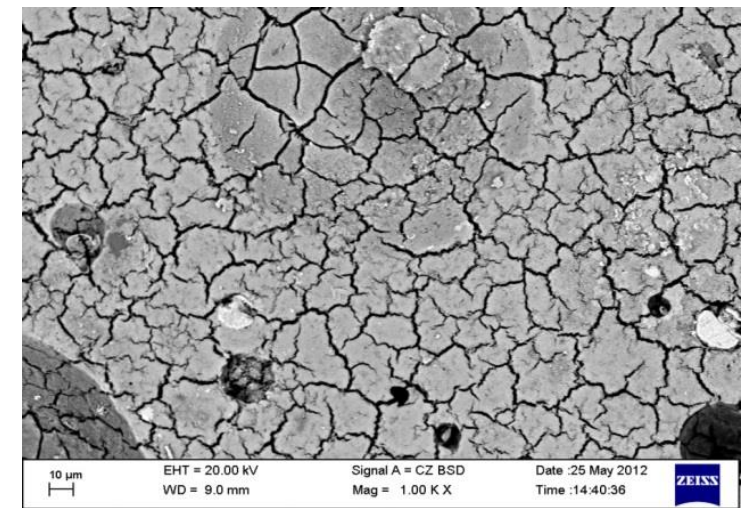

(g)

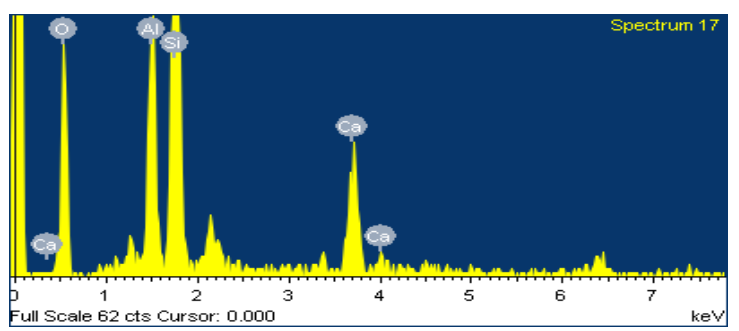

(h)

Figure 7. The microstructure and EDAX analysis of polished and etched specimens (e\& f)-AP3 vitrified at $1250^{\circ} \mathrm{C}$ and (g \& h)-AP4 vitrified at $1350^{\circ} \mathrm{C}$ 
The microstructure of AP4 looks entirely different from others due to formation of almost $100 \%$ anorthite grains. It may be seen, a strong pre-stress is produced on the glassy phase that surrounds the anorthite grains by the large difference in the thermal expansion coefficient between the glassy phase and the anorthite grain. Due to appropriate vitrification and stronger pre-stress, the strength of this anorthite porcelain is much higher than conventional clay-quartz-feldspar based porcelain body.

\section{Conclusions}

In the present investigation, when feldspar is replaced by BF and LD slag in full and partial in a quartz free fly ash based porcelain body, the anorthite crystals were found to be gradually formed with distinct changes in phase and microstructural features. The study revealed that BF and LD slag, the solid waste generated by iron and steel industry, can be used as an inexpensive source of $\mathrm{CaO}$ to produce anorthite porcelain, which has several advantages over conventional porcelain bodies with respect to its appropriate vitrification, higher mechanical strength and development of stronger pre-stress. Also utilization of fly ash, a deadly fine polluting waste, in tri-axial porcelain body substituting quartz in full amount was found to be highly beneficial. The scientific findings of the present study and technoeconomic advantages of the process will benefit the iron and steel industries for mitigation of pollution and environmental problems.

\section{Acknowledgement}

The author's wishes to thank The Director, CSIR-Central Glass and Ceramic Research Institute, Kolkata, India for his kind permission to carry out the project work as a part fulfilment of $\mathrm{M}$. Tech course in material science of the first author. The author also wishes to thank different characterization laboratory of CSIR-CGCRI and IIT Kharagpur, India for their continuous support.

\section{References}

Barbieri L., Bonfatti L., Ferrari A. M., Leonelli T., Manfrediui T. and Sttembre Blundo D. (1994), Relationship between microstructure and mechanical properties in fully vitrified stoneware, In proceedings of Eighth CIMTEC, World ceramic congress, Florence.

Carty W.M. and Senapati U. (1998), Porcelain-Raw materials, processing, Phase evolution and mechanical behaviour, J. Am. Ceram. Soc., 81(1), 3-20.

Cowie R.L. (1994), The epidemiology of tuberculosis in gold miners with silicosis, Am. J. Respir. Crit. Care Med, 150 (5 Pt 1): 1460-2. PMID 7952577.

Dana K. and Das S.K. (2003), High strength ceramic floor tiles containing Indian metallurgical slag, J. Mater Sci. Lett., 22, 387-389.

Dana K. and Das S.K. (2004), Partial substitution of feldspar by B. F. slag in triaxial porcelain: Phase and microstructural evolution, J. Eur. Ceram. Soc., 24, 3833-3839.

Dana K., Das S. and Das S.K. (2004), Effect of substitution of fly ash for quartz in triaxial kaolin-quartz-feldspar system, J. Eur. Ceram. Soc., 24, 3169-3175.

Dana K. and Das S.K. (2004), Evolution of microstructure in fly ash-containing porcelain body on heating at different temperatures, Bull. Mater. Sci., 27(2), 183-188.

Das S.K., Pal M., Ghosh J., Pathi K.V. and Mondal S. (2013), The effect of Basic oxygen furnace slag and fly ash additions in triaxial porcelain composition: phase and microstructural evolution, Transactions of the Indian Institute of Metals, 66 (3), 213-220.

Dondi M., Ercolani G., Melandri C., Mingazzini C. and Marsigh M. (1999), The chemical composition of porcelain stoneware tiles and its influence on microstructural and mechanical properties, Interceram, 48(2), 75-83.

Gottesfeld P., Nicas M., Kephart W., Balakrishnan K. and Rine H.R. (2008), Reduction of Respirable Silica Following the Introduction of Water Spray Applications in Indian Stone Crusher Mills, Int. J. Occup. Environ. Health, 14(2), 94-103. 
Haman K., Nakagawa Z and Hasegawa M. (1992), Improvement of mechanical strength of porcelain bodies by fine grinding of raw materials, J. Ceram. Soc. Jpn., 100, 1066-1069.

Haman K., Wu Y.H., Nakagawa Z. and Hasegawa M. (1991), Effect of grain size of quartz on mechanical strength of porcelain body, J. Ceram. Soc. Jpn., 99, 153-157.

Harada R. Sugiyama N. and Ishida $\mathrm{H}$. (1996), $\mathrm{Al}_{2} \mathrm{O}_{3}$-Strengthened feldspathic porcelain bodies: effects of the amount and particle size of alumina, Ceram. Eng. Sci. Proc., 17(1), 88-98.

Hillebrand W.F. and Lundell G.E.F. (1953), Applied inorganic analysis, Second edition, Wiley, New York.

Khandelwal S.K. and Cook R.L. (1970), Effect of alumina additions on crystalline constituents and fired properties of electrical porcelain, Am. Ceram. Bull., 49, 522-526.

Kumar S., Singh K.K. and Rao P.R. (2001), Effect of fly ash additions on the Mechanical and other properties of porcelainised stoneware tiles, J. Mater. Sci., 36, 5917-5922.

Leonelh C., Bondioli F., Veronesi P., Romagnoli M., Manfredini T. and Pellacani G.C. (2001), Enhancing the mechanical properties of porcelain stoneware tiles: a microstructural approach, J. Eur. Ceram. Soc., 21, 785-793.

Marghussian V.K. and Yekta B.E. (1994), Single fast fired wall tiles containing Iranian iron slags, Br. Ceram. Trans., 93(4), 141-145.

Mukherjee A.K. and Chakraborty T. K. (1999), Towards zero waste concepts and possibilities in Indian iron and steel industries, Proceeding of international workshop on environmental and waste management in iron and steel industries, Jamshedpur, India, December 2-3, 1999, 37-49 (ISSN:0971-9407).

Rahim S. A., M. Tech. thesis (2012), Utilization of industrial solid waste in producing ceramic tiles, IIT Kharagpur, India.

Sarkar R., Singh N. and Das S. K. (2010), Utilization of steel melting electric arc furnace slag for development of vitreous ceramic tile, Bull. Mater. Sci., 33(3), 293-298.

Sugiyama N., Harada R. and Ishida H. (1996), Densification process and mechanical Strength of feldspathic porcelain bodies, J. Ceram. Soc. Jpn., 104, 312-316.

Tai W.P., Kimura K. and Jinnai K. (2002), A new approach to anorthite porcelain bodies using non plastic raw materials, J. Eur. Cerram. Soc., 22, 463-470.

Taskiran M.U., Demirkol N. and CapogIn A. (2005), A new porcelainized stoneware material based on anorthite, J. Eur. Ceram. Soc., 25, 293-300. 